\title{
Tides and sea level variability decomposition in the Port of Santos Waterway
}

\author{
Carlos A.F. Schettini ${ }^{1} \oplus$, Eliane C. Truccolo ${ }^{1}$, José A.D. Mattos ${ }^{2}$, Daniel C.D.A. Benevides ${ }^{2}$
}

\author{
${ }^{1}$ Instituto Oceanográfico - Fundação Universidade do Rio Grande \\ (Av. Itália, Km 8, Rio Grande, RS, Brazil, 96203-000) \\ ${ }^{2}$ Van Oord, Serviços de Operações Marítimas \\ (Rua João Pessoa, 16 Sl 505 Centro - Santos - SP - 11013-000 - Brazil) \\ *Corresponding author: guto.schettini@gmail.com
}

Sea level variability encompasses a wide range of perturbations that span from seconds to millennia. The most relevant for contemporary coastal dynamics are those associated with wind waves, tides and storm surges, ranging temporally from seconds up to a few days (Dean and Dalrymple, 1984; Pugh, 1987), although seiches (Luettich et al., 2002) and tsunamis (Truccolo et al., 2012) may be also important. Sea level rise, at its actual trend of $3 \mathrm{~mm} /$ yr, cannot be put aside absolutely (Cazenave et al., 2014), however, its effects are synergic with the formers in longer time span and its variability vanishes in short time scales.

Tide is a commonly used denomination for sea level oscillations in the temporal band ranging from hours to days. The term a priori is referred to the oscillations caused by the astronomical forcing of periodic nature. However, sea level oscillations originating from meteorological forcing also occur in the same band, but have a stochastic nature. In this sense, they are called meteorological tides.

The astronomical tides are a group of long waves generated in the world ocean basins by the tidal generating force, centrifugal acceleration and Earth rotation (Pugh, 1987). Each wave is associated with a specific astronomic movement, inflicting to each wave a distinct period and angular speed. About three dozen 'pure' tidal waves are generated in the deep ocean basins, where the main one is the principal lunar semi-diurnal $\mathrm{M}_{2}$. As these waves propagate onto shallower continental shelves and further into coastal embayments, the pure ocean tides are distorted from their original form, producing shallow water harmonic tidal waves (overtides) such as the $\mathrm{M}_{4}$ and compound tides such as the $\mathrm{MS}_{4}$ (Parker, 1991). Since the

Submitted on: 29/April/2019

Approved on: 10/July/2019

http://dx.doi.org/10.1590/S1679-87592019026506707 original waves and its daughter waves present periodic nature, they can be identified using tidal harmonic analysis (Pugh, 1987; Pawlowicz et al., 2002).

The meteorological tides are produced by the atmosphere-ocean interactions and have a random nature. Changes in the atmospheric pressure can produce water level variations in a phenomenon called inverted barometer, and usually produces a change of $1 \mathrm{~cm}$ for each change of $1 \mathrm{~dB}$, and plays a small role in water level variability (Pugh, 1987). The main atmospheric influence is due to the wind stress acting on the sea surface. The wind effect on the oceans is well described by the Ekman theory (Pond and Pickard, 2013). At deep waters, the balance between the wind stress at the surface, the friction and the effect of Earth rotation will result in the depth-averaged transport over the wind influenced ocean layer to be orthogonal to the wind direction, anti-clockwise in the Southern Hemisphere. For the Brazilian Southeast shores, the dominant winds are northeasterly and are nearly parallel to the shore. This condition forces surface currents towards offshore, removing volume from the shelf producing water level fall. During the passage of cold fronts southerly dominates, pushing water towards the shore and sea level rise. Usually, the winds during cold fronts are stronger, so the positive meteorological tides are normally higher than the negative ones (Truccolo et al., 2006).

Low-frequency coastal sea level records have been widely used to study continental shelf dynamics and their relationship to the wind and atmospheric pressure. Most of the low-frequency sea-level rise and fall is firstly driven by local long-shore wind stress through the Ekman mechanism. These oscillations cause a cross-shelf barotropic gradient, which is in geostrophic balance with long-shore current (Thompson, 1981; Garret and Toulany, 1982; Chuang and Wiseman Jr, 1983; Allen and Denbo, 1984; 
Pugh, 1987; Schwing, 1992; Stech and Lorenzzetti, 1992). However, there is some evidence of nonlocal wind effects on coastal sea level for the South Brazil Bight region attributed to continental shelf waves (Castro and Lee, 1995).

The Port of Santos Waterway (PSW) comprises a 30 $\mathrm{km}$ long dredged channel that provides access to many terminals along the Santos Estuary. The waterway was accomplished from many engineering interventions aiming the channel deepening, with the present depth ranging between 15 and 23 m (Figure 1). The Santos Estuary presents a complex geometry, formed by straits between the continent and the São Vicente and Santo Amaro islands, with three inlets: São Vicente, at the west; Santos, at the center; and Bertioga, at the east. Santo Amaro and Bertioga channels, differently from the Santos channel, have been much less changed regarding their original depth.

The Santos Estuary present partially mixed estuarine structure (Ponçano and Gimenez, 1985), and tides play an important role in mixing and in the transport of scalars (Miranda et al., 1998; Moser et al., 2005). Harari and Camargo (1995) assessed the astronomical tides and sea level trend for a long record (44 years). They provide a

\section{(a)}
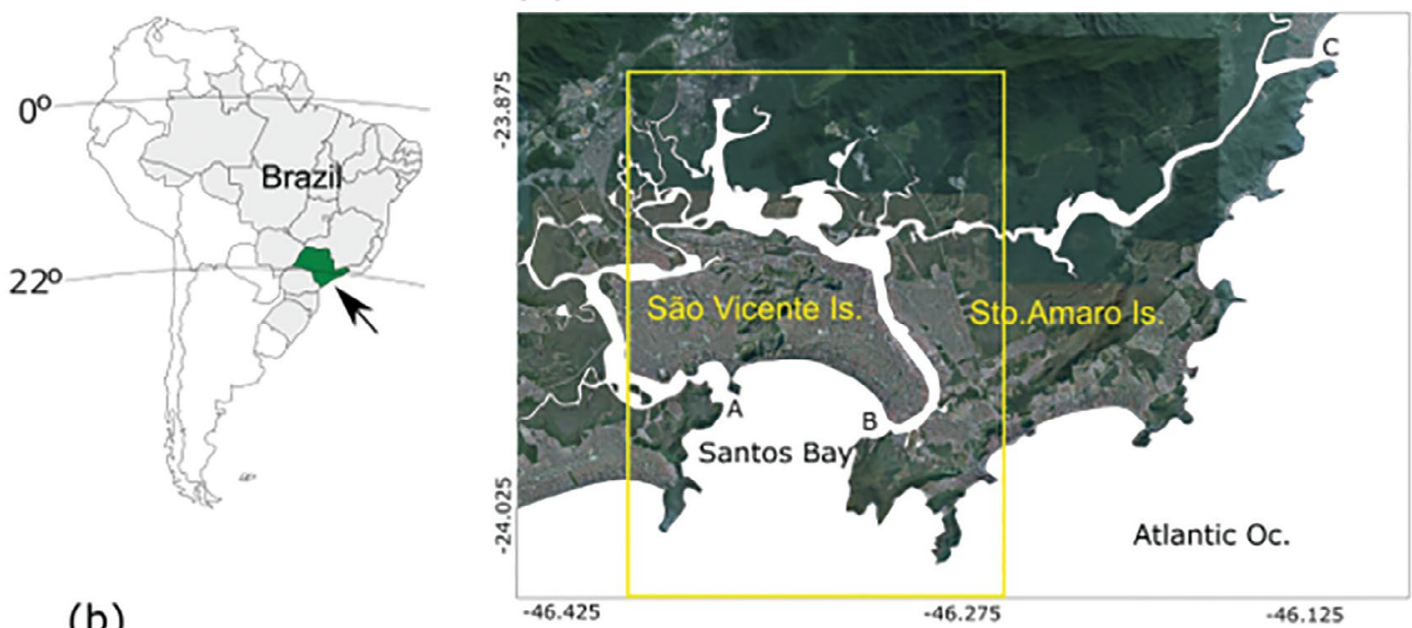

(b)

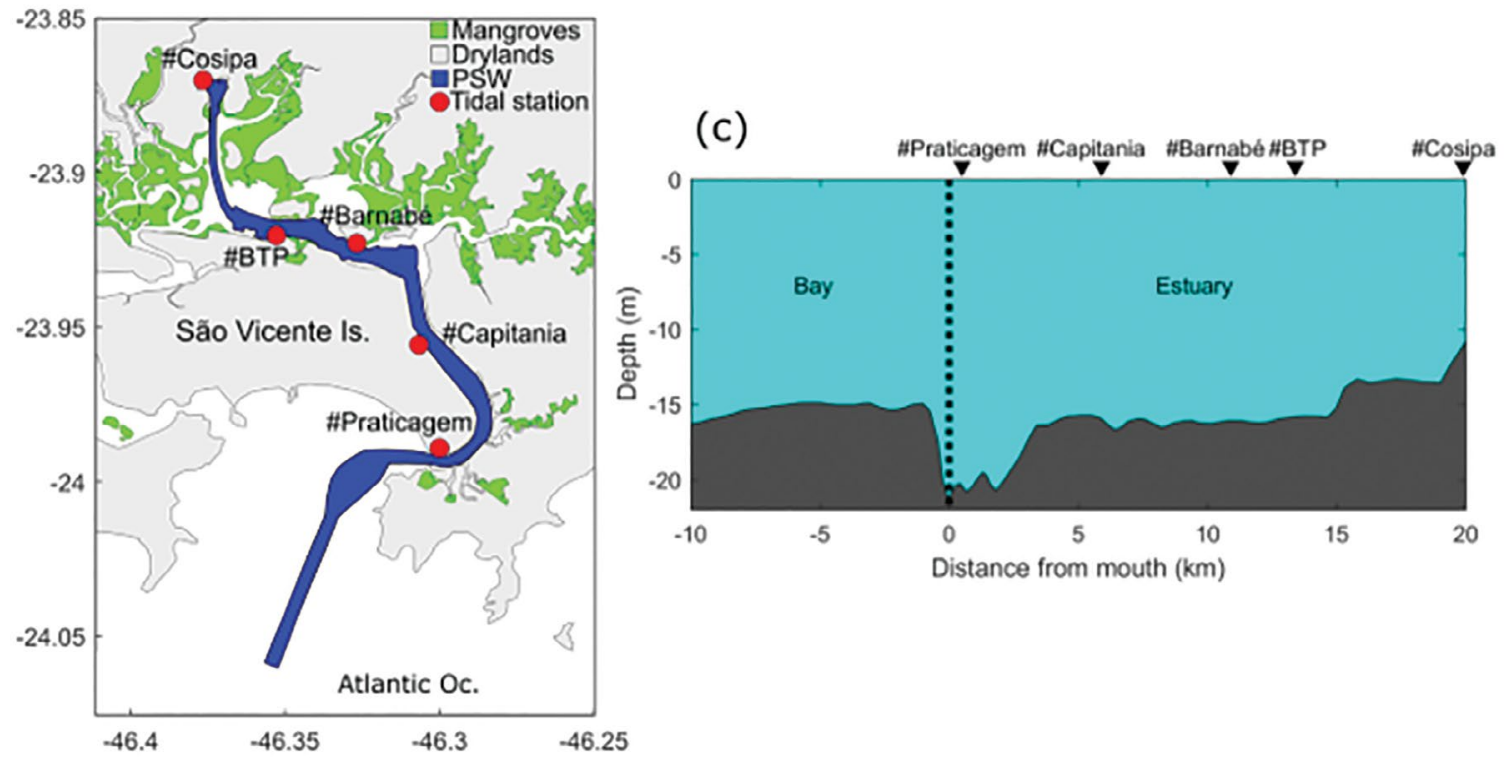

Figure 1. Localization of the Santos Channel. (a) overview of whole Santos Estuary with its three inlets: (A) São Vicente, (B) Santos and (C) Bertioga. (b) detail on the Port of Santos Waterway (PSW) with location of the tidal stations; and (c) longitudinal thalweg depth profile along the PSW with the location of the tidal stations. 
complete list of harmonic constituents solved for a whole year of data (1980).

In this note, we present by the first time an assessment of the water level variability and its decomposition along the PSW. Water level data were recorded in five stations along the Santos Estuary: (1) Praticagem, (2) Capitania, (3) Barnabé, (4) BTP and (5) Cosipa (Figure 1; Table 1). Data was recorded with tide gauges by Seabed model Orinoco, in 1-minute intervals, 30-s averaging at $1 \mathrm{~Hz}$. This comprised a unique data set since most water level records are available in larger sampling intervals (e.g., 10 minutes or more), allowing us to identify high- frequency oscillations such as seiches. Figure 2 shows the raw water level records. The vertical datum is the local one provided by the Brazilian Navy, except for \#BTP, which does not have it.

The time series were first evaluated by spectral analysis using fast Fourier transform by the Welch method (Emery and Thomson, 2001), and the water level was decomposed as

$$
\eta(t)=\eta_{\text {SubTf }}+\eta_{H}+\eta_{n H T f}+\eta_{\text {SupTf }}
$$

where the instantaneous level $\eta(t)$ is the sum of the level at subtidal frequency $\eta_{\text {SubTf }}$, the harmonic component $\eta_{H}$, the non-harmonic component at the tidal band $\eta_{n H T f}$, and the supratidal frequency $\eta_{\text {SupTf }}$ The subtidal band was considered for any oscillation with period $>30$ hours, while the supratidal band was for oscillations with a period $<1$ hour.

The $\eta_{\text {SubTf }}$ was obtained by filtering the time series with Butterworth filter (Roberts and Roberts, 1978) with a passband of 30 hours and a cut band of 40 hours. The $\eta_{H}$ was obtained by harmonic analysis using the package T-tide for $95 \%$ of confidence interval (Pawlowicz et al., 2002). Then we obtained the non-harmonic, tidal and supratidal band by

$$
\eta_{n H, T, \sup T}=\eta(t)-\left(\eta_{S u b T f}+\eta_{H}\right)
$$

which were further decomposed onto a non-harmonic tidal band ( $30 \mathrm{~h}>\mathrm{T}>1 \mathrm{~h}, \mathrm{~T}$ is period) and supratidal band ( $\mathrm{T}$ $<1 \mathrm{~h}$ ). The separation of these bands was made using a binomial recursive filter with a window as

$$
S_{i}=\frac{1}{4} S_{i-1}+\frac{1}{2} S_{i}+\frac{1}{4} S_{i+1}
$$

where S stands for any signal. The first and last elements of the series were preserved during the filtering by weighting with the second and penultimate with the proportion of 0.6:0.4 and vice-versa, respectively. Filter efficiency in band separation was assessed by the resulting power spectra analysis. The relative energy in each band was weighted by the variance of the synoptic period between the stations (from 18 May until 4 June $2018 \sim 17$ days).

The power spectral density (PSD) and the relationship between the PSD of the outermost station \#Praticagem and the other stations are presented in Figure 3. The semidiurnal is the most energetic band followed by the subtidal frequencies, and then the diurnal ones. Energy peaks of the terdiurnal and quarter diurnal are also very clear. For the bands of period higher than the quarter diurnal (frequency $<0.16 \mathrm{cph}$ ) the PSD are nearly identical, especially for frequencies smaller of the semi-diurnal band. For frequencies $>0.19 \mathrm{cph}$ (or period $<4.5 \mathrm{hr}$ ), the PSD for each station becomes singular. Particularly at this frequency, there is an opposite behavior between the outermost and innermost stations, so suggesting the grow of the 6-diurnal species along the estuary. In the bands between 1 and $0.5 \mathrm{cph}$ ( 1 and 2 hours) occurs a plateau of PSD with several smaller peaks, with higher energy at \#Praticagem, and lesser in \#BTP. Towards higher frequencies, occurs a steeper decay, and thus the behavior of each station differs from each other more evidently, with energy gradient towards the outer station. This can be understood as a larger effect of the wind wave and boat wake effects towards the mouth.

The PSD plateau with the band between 1 and 2 hours seems to be directly related with the basin natural

Table 1. Localization, distance from the Santos mouth, start and end (year, month, day and hour), and duration of the water level records.

\begin{tabular}{lcccccc}
\hline Station & Longitude & Latitude & $\begin{array}{c}\text { Distance from } \\
\text { mouth }(\mathrm{km})\end{array}$ & Start & End & $\begin{array}{c}\text { Duration } \\
(\mathrm{days})\end{array}$ \\
\hline Praticagem & $-46.3017^{\circ}$ & $-23.9917^{\circ}$ & 0.5 & $2018,5,3,13$ & $2018,7,2,17$ & 60.2 \\
Capitania & $-46.3081^{\circ}$ & $-23.9568^{\circ}$ & 5.9 & $2018,5,18,20$ & $2018,7,2,18$ & 44.9 \\
Barnabé & $-46.3333^{\circ}$ & $-23.9267^{\circ}$ & 10.9 & $2018,5,17,13$ & $2018,7,2,11$ & 45.9 \\
BTP & $-46.3562^{\circ}$ & $-23.9201^{\circ}$ & 13.4 & $2018,5,3,13$ & $2018,6,4,13$ & 32.0 \\
Cosipa & $-46.3782^{\circ}$ & $-23.8709^{\circ}$ & 19.9 & $2018,5,18,13$ & $2018,7,2,13$ & 45.0 \\
\hline
\end{tabular}



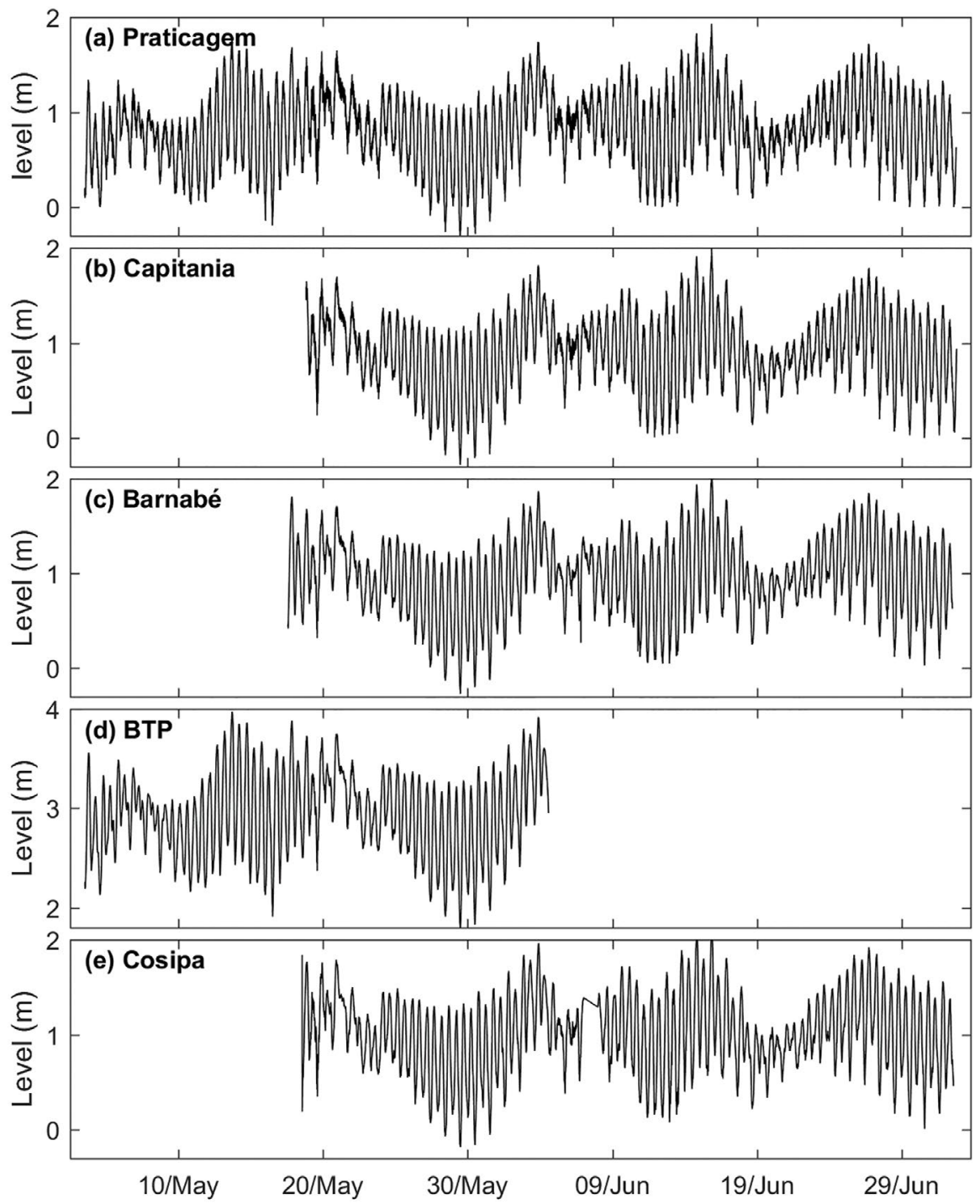

Figure 2. Time series of water level recorded along the Santos channel, during 2018.

oscillation, or seiche. For a basin with an open side, the period $\mathrm{T}$ of natural oscillation is given by the Merian formula (Pugh, 1987)

$$
T=\frac{4 L}{\sqrt{g H}}
$$

where $\mathrm{L}$ is the basin length, $\mathrm{g}$ is the gravity acceleration $\left(9.8 \mathrm{~m} / \mathrm{s}^{2}\right)$ and $\mathrm{H}$ is the depth. Seiches are generated usually by meteorological disturbing event (Trebitz, 2006), and may cause changes in the estuarine circulation (Dyer, 1982). In systems with complex geometry, it may occur in the production of multiple oscillations. For a $\sim 20 \mathrm{~km}$ long basin the natural oscillation would range between $\sim 1$ to $\sim 2$ hours for a depth of 25 and $10 \mathrm{~m}$, respectively (Figure 4), agreeing with the observations.

The signal decomposition is presented in Figure 5, and the variance contribution of each band is shown in Table 2 . All stations were reduced to the same datum, taken as the mean water lever during the synoptic period of study. Corroborating with what was highlighted by the spectral analysis, the water level variability is nearly identical along the estuary, excepting for the supratidal frequencies. The energy distributions in the bands were also nearly the same in the different stations, with the harmonic band accounting for $70 \%$, followed by the subtidal band with $\sim 27 \%$. The non-harmonic tidal frequencies accounted 

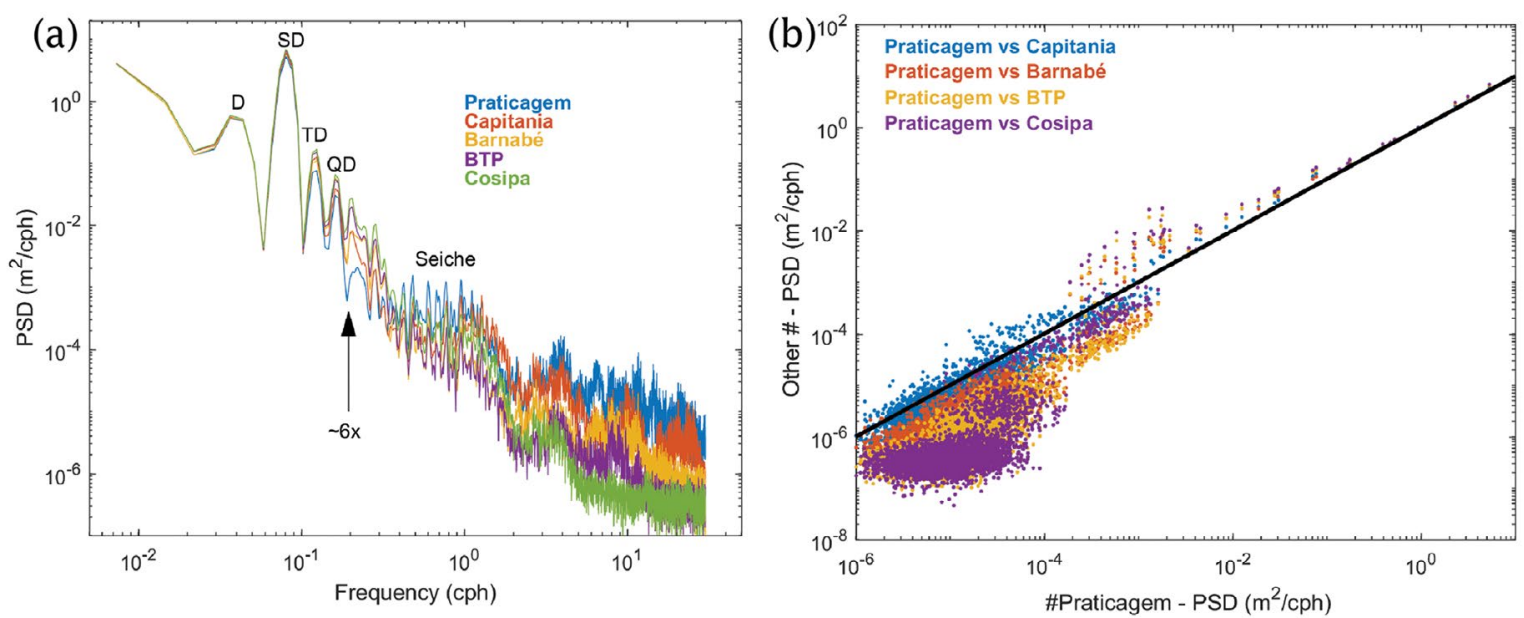

Figure 3. (a) Power spectral density (PSD) of the time series (D: diurnal; SD: semi-diurnal; TD: terdiurnal; QD: quarter diurnal; 6x six diurnal, frequency in cycles per hour) and (b) relationship of the PSD between \#Praticagem and the other stations, with reference line 1:1.

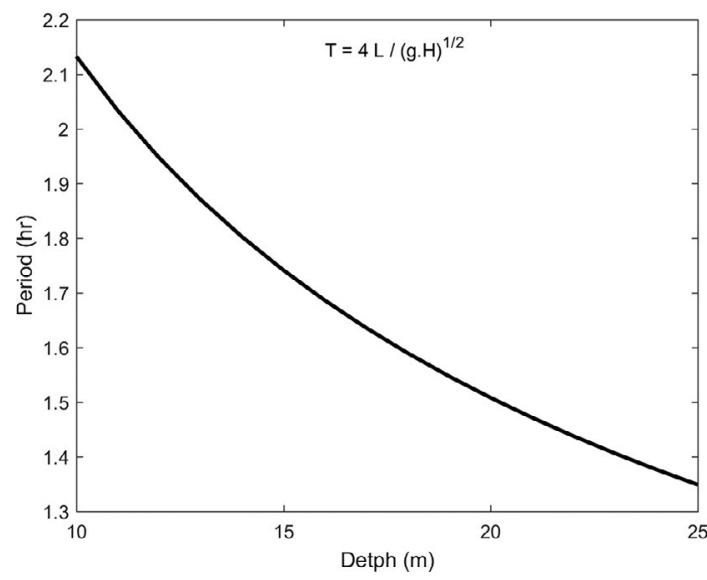

Figure 4. Period of natural oscillation as a function of the basin depth according to Eq. 4 for a $20 \mathrm{~km}$ long bay.

with $2-5 \%$ and are mainly due to residual semidiurnal, terdiurnal and quarter-diurnal energy not explained by the harmonic analysis. The seiche 'plateau' is evident, however, it accounts with very little energy. The supratidal band showed the most distinct behavior between the stations, with a decrease towards the estuary head.

The subtidal oscillations showed a variation range of $\sim 0.85 \mathrm{~m}$, with a progressive level decrease with $\sim 2$ day oscillations between 20 and 25 May, reaching the minimum level on 29 May, and increasing steadily to the end of the series (Figure 5b). The harmonic band displays the clear dominance of the semi-diurnal signal, with diurnal inequalities being more pronounced during the low tides. The neap tide occurred on 22 May, with a range of $0.68 \mathrm{~m}$, and spring tide occurred on 29 May, with a range of $1.46 \mathrm{~m}$. The non-harmonic oscillations in the tidal band were clearly larger at the beginning of the series when there were oscillations with $0.63 \mathrm{~m}$ of range, equivalent with the harmonic neap tidal range. The oscillations in this band decreased during the spring tide, and it seems to increase again with the waning of the tidal range for the next neap tidal period. The supratidal oscillations at the estuary head were negligible $(<0.03 \mathrm{~m}$; Figure $5 \mathrm{e})$, however at the estuary mouth they reach up to $0.35 \mathrm{~m}$. There are isotropic oscillations mainly between 21 and 24 May, which may be associated with wave conditions in the adjacent shelf. And there are also anisotropic positive oscillations distributed during all records, most likely being produced by ship wakes.

The behavior of the time series showed in Figure 5 suggests a nearly in phase water level oscillations in all stations. Indeed, considering the channel mean depth of $\sim 15 \mathrm{~m}$, the time required for a long shallow water wave to propagate $\sim 20 \mathrm{~km}$ would be of $\sim 25$ minutes (by $\sqrt{ } \mathrm{gH}$ ). From the harmonic tidal constituents, the phase lag between the \#Praticagem and \#Cosipa stations is $10^{\circ}$ for the $\mathrm{M}_{2}$, which represents $\sim 20$ minutes. Figure 6 present the observed data zoomed for 25 -hour period of neap and spring tide, and only a slightly phase lag can be noticed from \#Praticagem and \#Cosipa, occurring also a small amplification towards the head. This amplification was caused by the grown of the main tidal constituents (Figure 7). The $\mathrm{M}_{2}$ showed the largest 

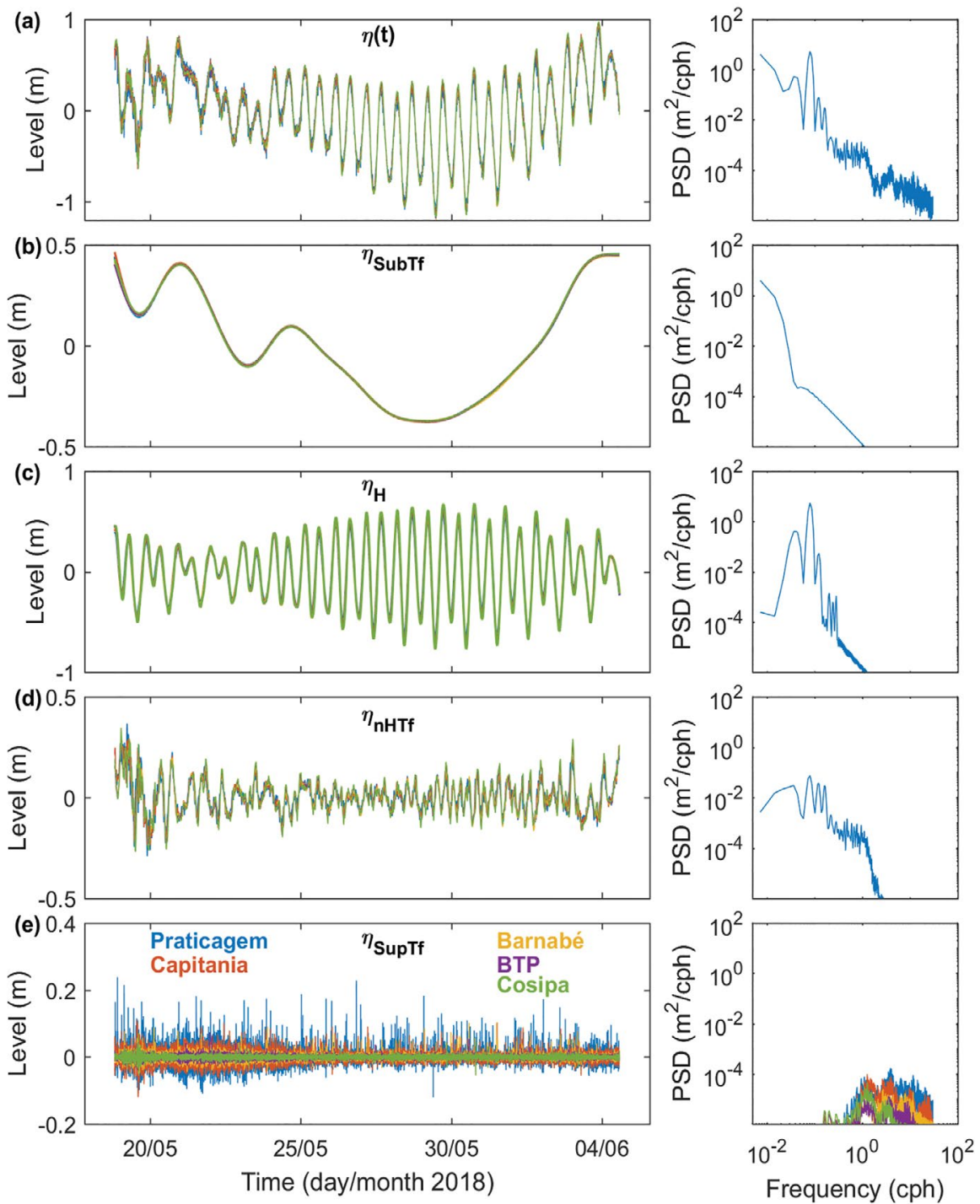

Figure 5. (Left) Time series of (a) observed water level in all stations and their decomposition in (b) subtidal, (c) harmonic, (d) non-harmonic at the tidal band and (e) supratidal frequencies. (Righ) PSD of the time series showed on the left side. From (a) to (d) are shown the PSD for \#Praticagem only. The color pattern is indicated in (e).

Table 2. Variance of observed water level signal $(\eta(t))$ and their decomposition in subtidal $\left(\eta_{\text {SubT }}\right)$, harmonic $\left(\eta_{H}\right)$, non-harmonic tidal $\left(\eta_{\text {zHTf }}\right)$ and supratidal $\left(\eta_{\text {Sup Tf }}\right)$ frequencies and the sum of the decomposed variances. The number in ( ) represents the $\%$.

\begin{tabular}{lcccccc}
\hline Station & $\eta(t)$ & $\eta_{\text {SubTf }}$ & $\eta_{H}$ & $\eta_{n \text { HTf }}$ & $\eta_{\text {SupTf }}$ & $\sum$ \\
\hline Praticagem & 1396 & $380(27.4)$ & $959(69.1)$ & $44(3.2)$ & $4.0(0.3)$ & 1386 \\
Capitania & 1503 & $413(27.6)$ & $1047(70.0)$ & $33(2.2)$ & $2.2(0.1)$ & 1496 \\
Barnabé & 1600 & $401(25.0)$ & $1152(71.9)$ & $48(3.0)$ & $1.1(0.1)$ & 1602 \\
BTP & 1777 & $490(27.6)$ & $1257(70.6)$ & $32(1.8)$ & $0.3(0.0)$ & 1780 \\
Cosipa & 1701 & $466(25.9)$ & $1244(69.0)$ & $92(5.1)$ & $0.9(0.1)$ & 1803 \\
\hline
\end{tabular}


(a) Neap tide
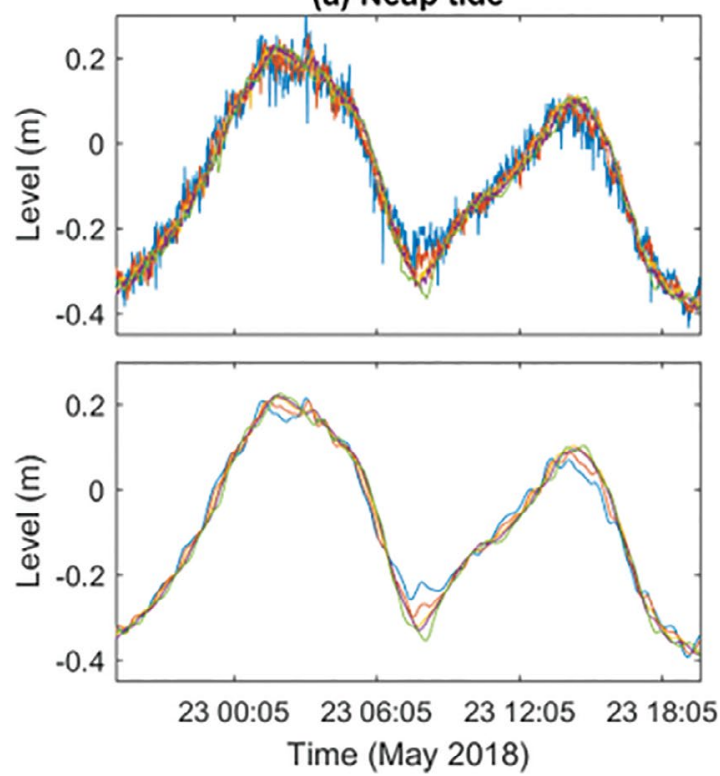

(b) Spring tide
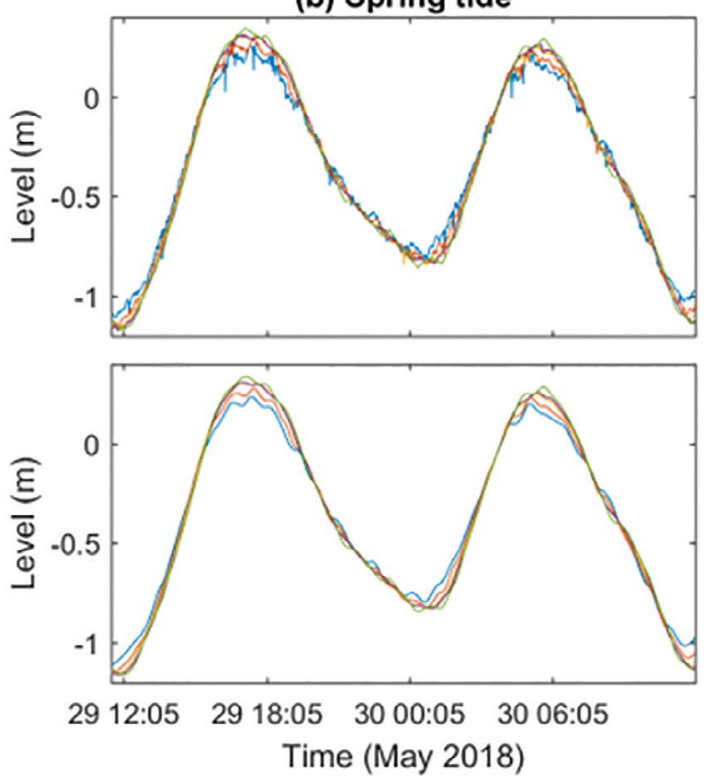

Figure 6. Water level time series of 25-hour period of neap (left) and spring (right). The top panels present the raw data, and the bottom panels present the filtered data. Colors pattern follows the same in Figure 5.

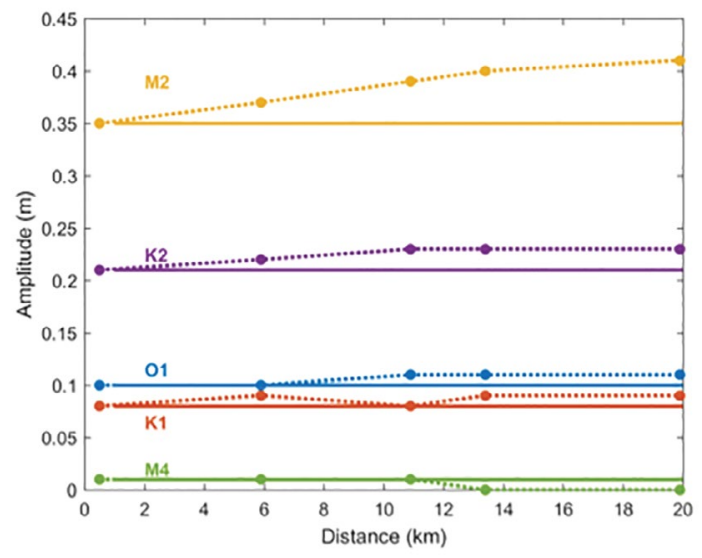

Figure 7. Amplitude variation of the main tidal constituents along the Santos channel. The straight line works as a reference for the constituent amplitude at \#Praticagem.

amplitude grew (17\%), while the others the amplitude grew was of $\sim 10 \%$, characterizing hypersyncronous behavior (Nichols and Biggs, 1987), what has been observed in other Brazilian estuaries (Truccolo and Schettini, 1999; Asp et al., 2018). The tidal behavior along an estuary can be dynamically balanced between channel convergence, which produces tidal grow, and friction, which reduces the range (Friedrichs, 2010), so in the PSW the former prevail.

Table 3 presents the harmonic constituents along the PSW based on the synoptic period of data $(\sim 15$ days). The main diurnal (O1 and K1) and semi-diurnal (M2 and S2) constituents were solved. The results agree well with the ones present by Harari and Camargo (1995) for a whole year data (1980) at a nearby station to Capitania. As tides propagate over shallow waters and into estuaries, friction plays a role in transferring energy from the main tidal constituents to higher frequency overtides and compound tides (Parker, 1991). The frictional effects can be weighted by a shallowness parameter given by the ratio of the tidal amplitude to the mean depth $(\mathrm{a} / \mathrm{H})$, and by the ratio between of the main M2 overtide, the M4, to the former (aM4/aM2) (Friedrichs and Aubrey, 1988). The former ranges between 0.02 and 0.05 during neap and spring tides, respectively, and the later is $\sim 0.03$. Both ratios clearly indicate the frictionless nature of tide propagation along the channel.

The main results of our analysis are: (1) the harmonic signal accounted for $\sim 70 \%$ of the sea level variability and $\sim 27 \%$ of it was due to subtidal effects; (2) there are seiches 
Table 3. Harmonic tidal constituents (at 95\% of confidence level) for the synoptic period ( 17 days). Amplitude in m, phase in degrees. a: amplitude; ae: amplitude error; p: phase; pe: phase error. Values in ( ) for Capitania station are from 1980 whole year analysis by Harari and Camargo (1995).

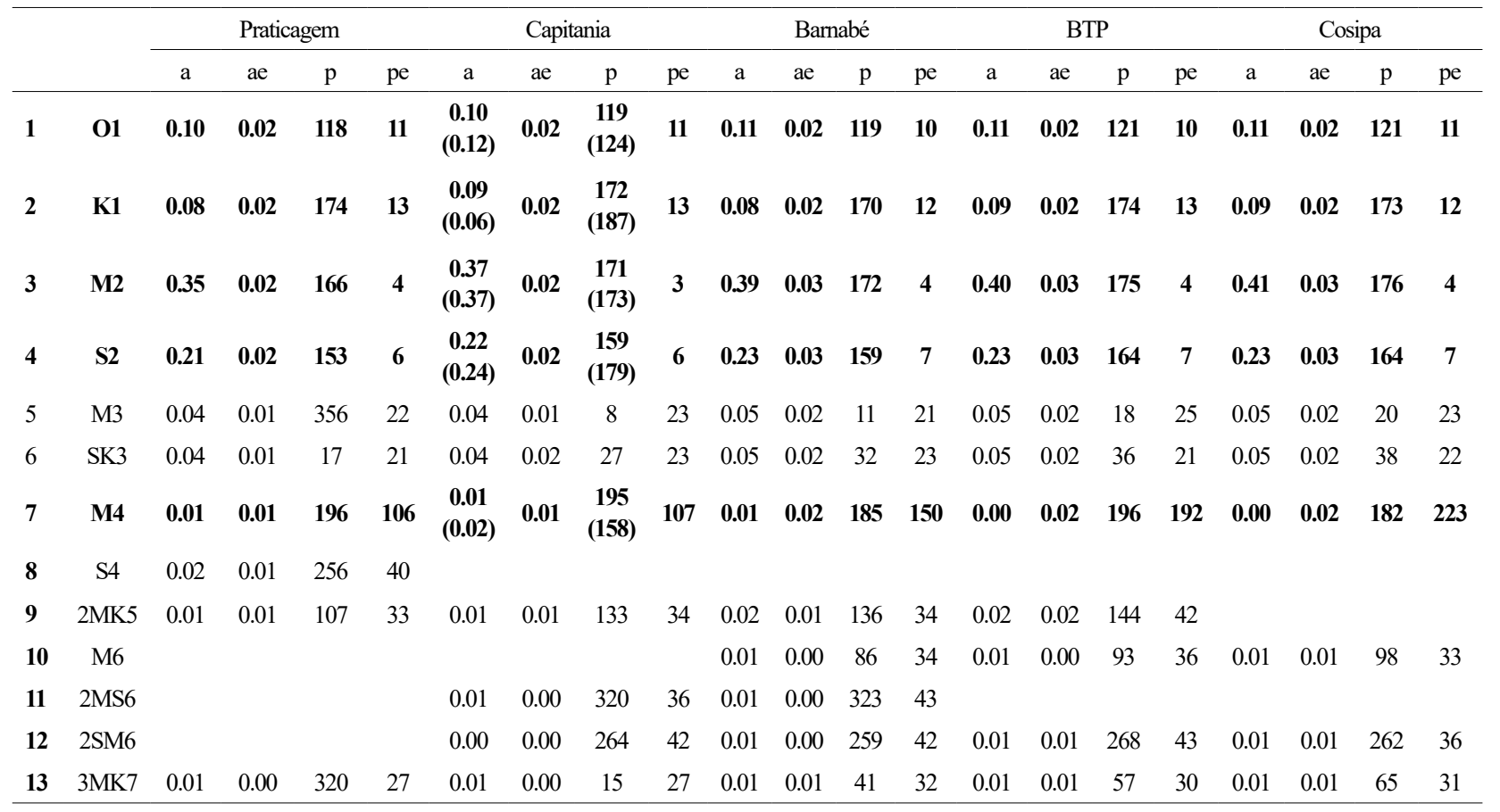

with variable period around 1.5 hour; (3) there is amplification of the harmonic signal towards the head, especially of the main semi-diurnal lunar $\mathrm{M}_{2}$; (4) the sea-level perturbations at tidal and subtidal bands propagates with little frictional effects; (5) supratidal oscillations vanishes completely at the head.

\section{REFERENCES}

ALLEN, J. S. \& DENBO, D. W. 1984. Statistical characteristics of the large-scale response of coastal sea level to atmospheric forcing. Journal of Physical Oceanography, 14, 1079-1094.

ASP, N. E., GOMES, V. J. C., SCHETTINI, C. A. F., SOUZA-FILHO, P. W. M., SIEGLE, E., OGSTON, A. S., NITTROUER, C. A., SILVA, J. N. S., NASCIMENTO JR., W. R., SOUZA, S. R., PEREIRA, L. C. C. \& QUEIROZ, M. C. 2018. Sediment dynamics of a tropical tide-dominated estuary: turbidity maximum, mangroves and the role of the Amazon River sediment load. Estuarine, Coastal and Shelf Science, 214, 10-24.

CASTRO, B. M. \& LEE, T. N. 1995. Wind-forced sea level variability on the southeast Brazilian shelf. Journal of Geophysical Research, 100, 16045-16056.

CAZENAVE, A., DIENG, H. B., MEYSSIGNAC, B., VON SCHUCKMANN, K., DECHARME, B. \& BERTHIER, E. 2014. The rate of sea-level rise. Nature Climate Change, 4, 358-361.

CHUANG, W. S. \& WISEMAN JR, W. J. 1983. Coastal sea level response to frontal passages on the Louisiana-Texas Shelf. Journal of Geophysical Research, 88, 2615-2620.

DEAN, R. G. \& DALRYMPLE, R. A. 1984. Water wave mechanics for engineers and scientists, New Jersey, World Scientific.
DYER, K. R. 1982. Mixing caused by lateral internal seiching within a partially mixed estuary. Estuarine Coastal Shelf Science, 15, 443457.

EMERY, W. J. \& THOMSON, R. E. 2001. Data analysis methods in physical oceanography, New York, Elsevier.

FRIEDRICHS, C. T. 2010. Barotropic tides in channelized estuaries. In: VALLE-LEVINSON, A. (ed.) Contemporary issues in estuarine physics. Cambridge: Cambridge University Press.

FRIEDRICHS, C. T. \& AUBREY, D. G. 1988. Non-linear tidal distortion in shallow well-mixed estuaries: a synthesis. Estuarine, Coastal and Shelf Science, 27, 521-545.

GARRETT, C. \& TOULANY, B. 1982. Sea level variability due to meteorological forcing in the Northeast Gulf of St. Lawrence. Journal of Geophysical Research, 87, 1968-1978.

HARARI, J. \& CAMARGO, R. 1995. Tides and mean sea level variabilities in Santos (SP), 1944 to 1999. Relatório Interno do Instituto Oceanográfico (São Paulo), 36, 1-15.

LUETTICH Jr., R. A., CARR, S. D., REYNOLDS-FLEMING, J. V., FULCHER, C. W. \& McNINCH, J. E. 2002. Semi-diurnal seiching in a shallow, micro-tidal lagoonal estuary. Continental Shelf Research, 22, 1669-1681.

MIRANDA, L. B., CASTRO, B. M. \& KJERFVE, B. 1998. Circulation and mixing due to tidal forcing in the Bertioga Channel, São Paulo, Brazil. Estuaries and Coasts, 21, 204-214.

MOSER, G. A. O., GIANESElla, S. M. F., ALBA, J. J. B., BÉRGAMO, A. L., SALDANHA-CORREAA, F. M. P., MIRANDA, L. B. \& HARARI, J. 2005. Instantaneous transport of salt, nutrients, suspended matter and chlorophyll-a in the tropical estuarine system of Santos. Brazilian Journal of Oceanography, 53,115-127. 
NICHOLS, M. M. \& BIGGS, R. B. 1985. Estuaries. In: DAVIS, R. A. (ed.) Sedimentary Environments. New York: SpringerVerlag.

PARKER, B. B. 1991. The relative importance of the various nonlinear mechanisms in a wide range of tidal interactions (Review). In: PARKER, B. B. (ed.) Tidal Hydrodynamics. New York: John Wiley and Sons.

PAWLOWICZ, R., BEARDSLEY, B. \& LENTZ, S. 2002. Classical tidal harmonic analysis including error estimates in MATLAB using T_TIDE. Computers \& Geosciences, 28, 929-937.

PONÇANO, W. L. \& GIMENEZ, A. F. 1985. Sobre o padrão de circulação do Estuário Santista. Revista Brasileira de Geociências, 15, 317-321.

POND, S. \& PICKARD, G. L. 2013. Introductory Dynamical Oceanography, Oxford, Butterworth-Heinemann.

PUGH, D. T. 1987. Tides, surges and mean sea-level: a handbook for engineers and scientists, New York, Wiley-Blackwell.

ROBERTS, J., ROBERTS, T.D., 1978. Use of Butterworth lowpass filter for oceanographic data. Journal of Geophysical Research 83(C11), 5510-5514.

SCHWING, F. B. 1992. Subtidal response of Scotian Shelf circulation to local and remote forcing. Part I: Observations. Journal of Physical Oceanography, 22, 523-541.
STECH, J. L. \& LORENZZETTI, J. A. 1992. The response of the South Brazil Bight to the passage of wintertime cold fronts. Journal of Geophysical Research, 97, 9507-9520.

THOMPSON, K. R., 1981. The response of southern North Sea elevations to oceanographical and meteorological forcing. Estuarine, Coastal and Shelf Science, 13, 287-301.

TREBITZ, A. S. 2006. Characterizing Seiche and Tide-driven Daily Water Level Fluctuations Affecting Coastal Ecosystems of the Great Lakes. Journal of Great Lakes Research, 32, 102116.

TRUCCOLO, E. C. \& SCHETTINI, C. A. F. 1999. Marés astronômicas na Baía da Babitonga, SC. Notas Técnicas da Facimar, 3, 57-66.

TRUCCOLO, E. C., FRANCO, D. \& SCHETTINI, C. A. F. 2006. The low frequency sea level oscillations in the northern coast of Santa Catarina, Brazil. Journal of Coastal Research, 39, 547-552.

TRUCCOLO, E. C., SCHETTINI, C. A. F. \& ALMEIDA, D. C. 2012. The 2004 Sumatra tsunami effect on the Itajaí-Açu estuary water level, Santa Catarina, Brazil. Brazilian Journal of Oceanography, 60, 461-466. 